\title{
Effect of Solar Proton Events on the Middle Atmosphere During the Past Two Solar Cycles as Computed Using a Two-Dimensional Model
}

\author{
Charles H. Jackman, Anne R. Douglass, ${ }^{1}$ Richard B. Rood, and Richard D. McPeters \\ Laboratory for Atmospheres, NASA Goddard Space Flight Center, Greenbelt, Maryland \\ Paul E. Meade
}

Department of Astrophysical, Planetary, and Atmospheric Sciences, University of Colorado, Boulder

\begin{abstract}
Daily average solar proton flux data for the years 1963-1984 (two solar cycles) have been used in a proton energy degradation scheme to derive ion pair production rates and, subsequently, $\mathrm{HO}_{x}(\mathrm{H}, \mathrm{OH}$, $\left.\mathrm{HO}_{2}\right)$ and $\mathrm{NO}_{x}\left(\mathrm{~N}, \mathrm{NO}, \mathrm{NO}_{2}\right.$ ) production rates. These $\mathrm{HO}_{x}$ and $\mathrm{NO}_{x}$ production rates are computed in a form suitable for inclusion in an atmospheric two-dimensional time-dependent photochemical model. The $\mathrm{HO}_{x}$ increases, although large for certain solar proton events (SPEs), are relatively short-lived because the $\mathrm{HO}_{x}$ species have lifetimes of only hours in the middle atmosphere. For longer-lived $\mathrm{NO}_{x}$ species, increases are important for 2-4 months past the more intense SPEs but are generally negligible 6 months after the SPE. The only exception to this scenario was the gigantic August 1972 SPE, whose stratospheric effects lasted about a year past the event. Comparisons of model results with the ozone data from the Nimbus 4 backscattered ultraviolet (BUV) instrument indicate relatively good agreement in the time dependence and magnitude of the ozone depletion for the middle stratosphere between the model and measurements for the August 1972 SPE and for 2 months past the event. The model predictions for the August 1972 SPE indicate at most a $1 \%$ decrease in total ozone at the highest latitudes with a significant interhemispheric difference. The model predicts a larger middle latitude stratospheric ozone change in the southern than the northern hemisphere caused by the difference in seasons between the two hemispheres. The computed ozone decreases associated with the $\mathrm{HO}_{x}$ and $\mathrm{NO}_{x}$ increases are substantial in the upper stratosphere at high latitudes for only a few SPEs in the 22 years studied. A mechanism is presented for transport of NO from the stratosphere to the ground, which may be involved in the enhancements in nitrate fluxes noticed in Antarctic deposition data. Our computations, however, indicate that the SPE contributions to these nitrate fluxes (even for the August 1972 SPE) are probably small.
\end{abstract}

\section{INTRODUCTION}

In order to comprehend fully humankind's influence on the middle atmosphere, the natural changes must first be understood. Some natural changes in the middle atmosphere related to the solar cycle are caused by solar proton events (SPEs). SPEs have been investigated since the late 1960 s for possible effects on the middle atmosphere. Solar protons from SPEs produce ionizations, dissociations, dissociative ionizations, and excitations in the middle atmosphere. Either directly or through a photochemical sequence, reactive $\mathrm{HO}{ }_{x}\left(\mathrm{H}, \mathrm{OH}, \mathrm{HO}_{2}\right)$ and $\mathrm{NO}_{x}\left(\mathrm{~N}, \mathrm{NO}, \mathrm{NO}_{2}\right)$ are produced. These $\mathrm{HO}_{x}$ and $\mathrm{NO}_{x}$ constituents are important because they can lead to the destruction of ozone.

Ozone depletions have been observed during and after nine separate SPEs over the past two solar cycles [Weeks et al., 1972; Heath et al., 1977; McPeters et al., 1981; Thomas et al., 1983; Solomon et al., 1983a; McPeters and Jackman, 1985]. SPEs have also been observed to increase NO during one SPE [McPeters, 1986]. The ozone depletions for eight of the SPEs (November 1969, January and September 1971, June and August 1979, October 1981, and July and December 1982) are believed to be primarily caused by the $\mathrm{HO}_{x}$

\footnotetext{
${ }^{1}$ Now at Universities Space Research Association, Columbia Maryland.

Copyright 1990 by the American Geophysical Union.

Paper number 90JD00089.

0148-0227/90/90JD-00089\$05.00
}

production of SPEs. Those $\mathrm{HO}_{x}$-caused ozone depletions are confined to the mesosphere and upper stratosphere, where $\mathrm{HO}_{x}$ species account for most of the ozone loss [Jackman et al., 1986], and are relatively short-lived, since $\mathrm{HO}_{x}$ lifetimes and $\mathrm{O}_{3}$ recovery times in this region are only of the order of hours.

The ozone depletion observations of the August 1972 SPE indicated a short-lived $\mathrm{HO}_{x}$-caused component in the mesosphere and upper stratosphere and a relatively long-lived (approximately months) $\mathrm{NO}_{x}$-dominated component in the middle stratosphere. This event was the largest of the past two solar cycles and has been studied theoretically by several groups [e.g., Crutzen et al., 1975; Fabian et al., 1979; Solomon and Crutzen, 1981; Reagan et al., 1981; Rusch et al., 1981].

Jackman et al. [1980] focused on the SPE production of odd nitrogen over 26 years (1954-1979), and Jackman and Meade [1988] investigated in detail the production of odd nitrogen during the years 1978 and 1979 for a possible SPE-related influence on the limb infrared monitor of the stratosphere (LIMS) measured constituents $\mathrm{NO}_{2}$ and $\mathrm{HNO}_{3}$. Jackman et al. [1980] found that the SPE source has a large variability in its yearly contribution to odd nitrogen and can dominate the largest odd nitrogen source, $\mathrm{N}_{2} \mathrm{O}$ oxidation, for geographic latitudes greater than $50^{\circ}$ during certain years. Jackman and Meade's [1988] calculations showed that the SPE-related odd nitrogen changes (1) were confined mainly to the region above $10 \mathrm{mbar}$ and latitudes higher than $50^{\circ}$ in both hemispheres, (2) depended primarily 
on the background local abundance of odd nitrogen as well as on the altitude and season, (3) are important for 2-3 months after the SPEs but are generally negligible 6 months after the SPE, and (4) should have caused negligible changes in background $\mathrm{NO}_{2}$ and $\mathrm{HNO}_{3}$ during the LIMS measurement period.

Here we investigate the effects of two solar cycles (19631984) of solar protons on the middle atmosphere by investigating odd nitrogen $\left(\mathrm{NO}_{y}\right)$ as well as ozone. Our calculations indicate the extent to which solar protons influence the middle atmosphere constituents and if SPEs need to be taken into consideration for studies of long (solar cycle) time scales.

\section{Proton Flux Data and SPE Production OF Odd Nitrogen $\left(\mathrm{NO}_{y}\right)$ AND $\mathrm{HO}_{x}$}

Proton fluxes from T. Armstrong and colleagues (University of Kansas, private communication, 1986) allow for a daily computation of ion pair production and $\mathrm{NO}_{y}$ production due to SPEs for the time period 1963-1984. The proton fluxes are given in integral form (units are $\mathrm{cm}^{-2} \mathrm{~s}^{-1} \mathrm{sr}^{-1}$ ) for energies greater than 10,30, and $60 \mathrm{MeV}$ and are zero for most days in the 22-year period (1963-1984) with about 900 days containing nonzero values. These proton data are discussed by Armstrong et al. [1983]. We have derived differential proton spectra from those data and used those data in a manner similar to that given by Jackman and Meade [1988]. We fit the proton data from T. Armstrong with an empirical formula of a power law form, given as

$$
d F / d E=F_{0}\left(E / E_{0}\right)^{-n} \mathrm{~cm}^{-2} \mathrm{~s}^{-1} \mathrm{sr}^{-1} \mathrm{MeV}^{-1}
$$

where $F$ is the proton flux, $F_{0}$ and $n$ are parameters, $E$ is the proton energy in megaelectron volts $(\mathrm{MeV})$, and $E_{0}$ is simply set to $1 \mathrm{MeV}$ for all fits. The best fit to the proton data was found using a least squares fitting solution: parameter $F_{0}$ varied over a large range, while values for $n$ were close to 2 . These fits were generally within $10 \%$ over the proton energy range for most days of spectra data. We assume our power law form is valid over the proton energy range from 5 to 100 $\mathrm{MeV}$. We extended the lower limit of the energy range from $10 \mathrm{MeV}$ (given by Jackman and Meade [1988]) to $5 \mathrm{MeV}$ because we wanted a better estimate of the mesospheric source of odd nitrogen over the two solar cycle time period 1963-1984. A significant amount of extra odd nitrogen production is derived from those protons between 5 and $10 \mathrm{MeV}$ which deposit energy in the mesosphere, and the small extrapolation from 10 to $5 \mathrm{MeV}$ is believed to give at least a reasonable estimate of the proton flux at these lower energies.

The protons were divided up into 60 monoenergetic energy intervals, all assumed to be isotropic, and then were degraded in energy following Jackman et al. [1980]. Protons in the 5-100 MeV energy range deposit most of their energy between about 100 and $35 \mathrm{~km}$. We compute a daily ion pair production over the 22-year time period in a form suitable for inclusion in our two-dimensional model.

The ion pair production computed from the daily average proton flux data of $\mathrm{T}$. Armstrong compares favorably with the ion pair production computed using the hourly average proton flux data found in the Solar Geophysical Data publication for most SPEs. However, for the August 1972 SPE the ratio of the hourly computed ion pair production to the
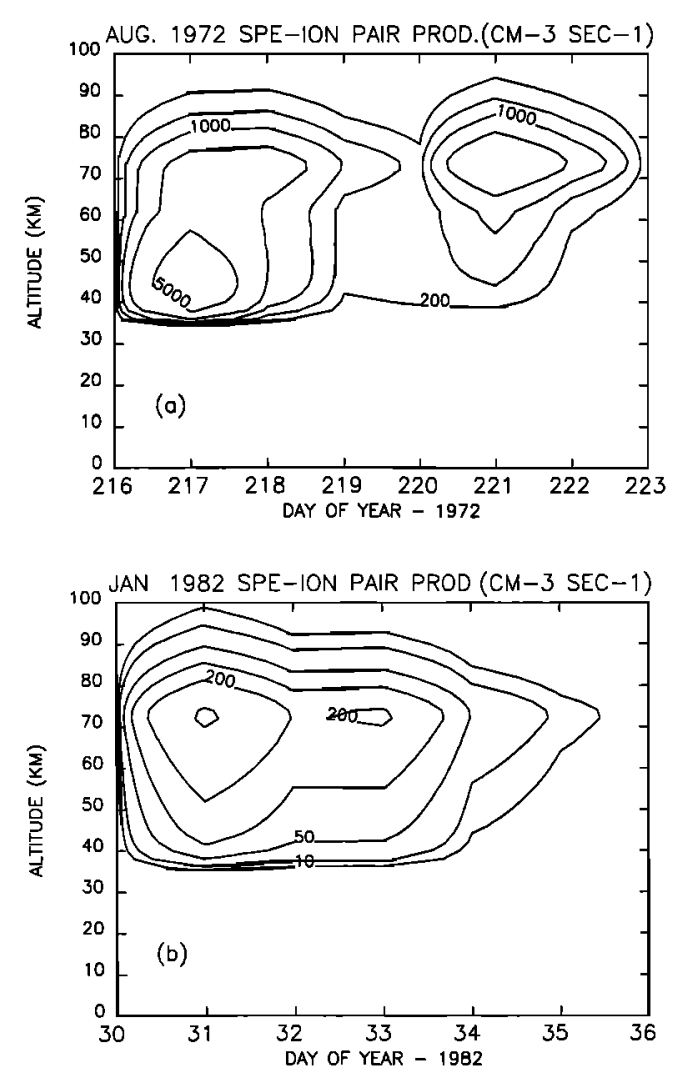

Fig. 1. Daily average ion pair production for (a) the August 1972 solar proton event; contours represented are $200,500,1000,2000$, and $5000 \mathrm{~cm}^{-3} \mathrm{~s}^{-1}$; and $(b)$ the January 1982 solar proton event; contours represented are $10,20,50,100,200$, and $500 \mathrm{~cm}^{-3} \mathrm{~s}^{-1}$.

daily computed ion pair production ranges from about 3.7 in the stratosphere to near 1.0 in the mesosphere. We have normalized the daily to the hourly computed ion pair production for this one SPE because the hourly computed ion pair production is believed to be more accurate than the daily computed ion pair production.

The daily average ion pair production for two SPEs (August 1972 and January 1982) is shown in Figure 1. The gigantic SPE in August 1972 is presented in Figure 1 $a$. This event had a rather hard spectrum of particles (with higher energy protons dominating) during the first couple of days, peaking in ion pair production near $8000 \mathrm{~cm}^{-3} \mathrm{~s}^{-1}$ between 40 and $50 \mathrm{~km}$ on day 217 . Later in the August 1972 SPE (days 220-222), the peak in ion pair production occurred at the higher altitudes (between 70 and $80 \mathrm{~km}$ ) when a softer spectrum of particles was dominant (lower-energy protons). Other SPEs during the 22-year period studied are not as intense as the first couple of days of the August 1972 SPE, and their proton spectra are typically softer. The January 1982 SPE, whose ion pair production is shown in Figure $1 b$, is a good example of this type of SPE. Its ion pair production has a peak over $500 \mathrm{~cm}^{-3} \mathrm{~s}^{-1}$ between 70 and $80 \mathrm{~km}$ on day 31 .

These 22 years of changing solar condition are represented by the changing sunspot number in Figure $2 a$. Figure $2 b$ indicates the ion pair production at $44 \mathrm{~km}$ for the same 22-year period at geomagnetic latitudes greater than $60^{\circ}$. Note that more SPEs tend to occur when the sunspot number is high. The maxima in ion pair production, how- 


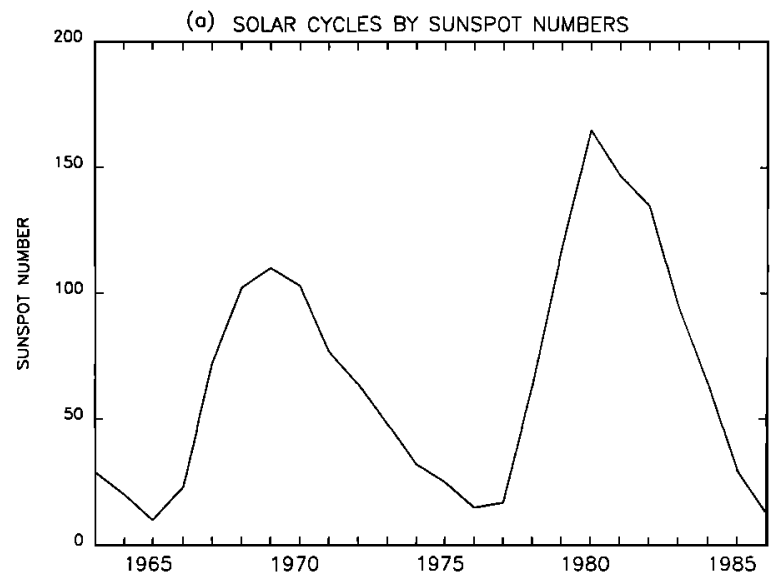

(b) ION PAIR PRODUCTION (CM-3 SEC-1) AT $44 \mathrm{KM}$

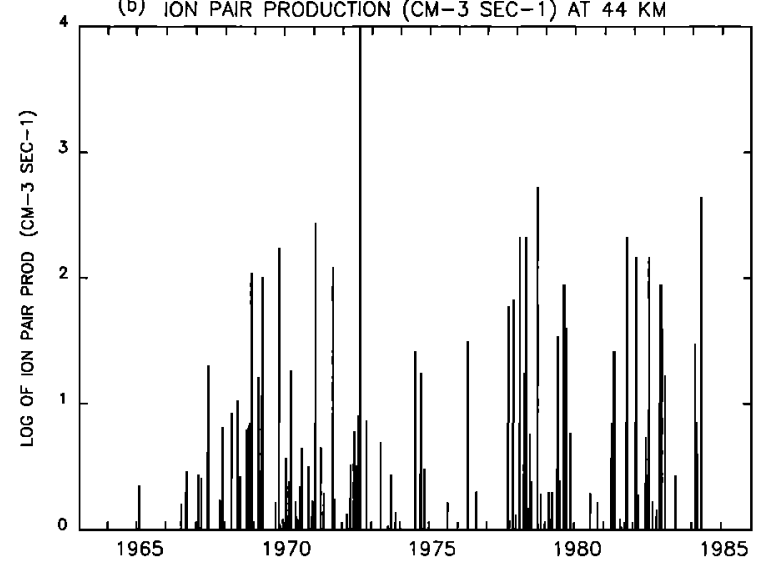

Fig. 2. (a) Sunspot number $\left(R_{z}\right)$ taken from the Solar Geophysical Data publication. (b) $\log _{10}$ of the computed ion pair production $\left(\mathrm{cm}^{-3} \mathrm{~s}^{-1}\right)$ at $44 \mathrm{~km}$.

ever, do not necessarily correspond to the maxima in sunspot number. In fact, during the last solar cycle the ion pair production at $44 \mathrm{~km}$ maximized just before and just after the maximum in sunspot number.

The production of $\mathrm{NO}_{y}$ species by SPEs has been predicted since the mid-1970s [Crutzen et al., 1975]. The NO increase after the July 1982 SPE was inferred from the Nimbus 7 solar backscattered ultraviolet (SBUV) instrument to be about $6 \times 10^{14} \mathrm{NO}$ molecules $\mathrm{cm}^{-2}$ at polar latitudes [McPeters, 1986], in good agreement with our calculated NO increase of $7 \times 10^{14} \mathrm{NO}$ molecules $\mathrm{cm}^{-2}$ in the polar cap. This calculation assumed 1.25 nitrogen $(\mathrm{N})$ atoms produced per ion pair which is similar to the value given by Porter et al. [1976], derived using a detailed theoretical energy degradation computation. The agreement between the predicted and measured NO increase following the July 1982 SPE has given us confidence in the reliability of the computations for $\mathrm{NO}_{y}$ species' increase caused by SPEs. We therefore assume that $1.25 \mathrm{~N}$ atoms are produced per ion pair for all base model computations in this paper.

The production of $\mathrm{HO}_{x}$ species by SPEs has been predicted since the early 1970s [Swider and Keneshea, 1973]. The $\mathrm{HO}_{x}$ produced by SPEs is believed to be responsible for most of the ozone depletion observed in eight SPEs. Solomon et al. [1983a, b] found good agreement between model predictions and observations by the Solar Mesosphere Explorer (SME) satellite of ozone depletion caused by the $\mathrm{HO}_{x}$ increases due to the July and December 1982 SPEs. Jackman and McPeters [1985] also found good agreement between model predictions and SME observations of ozone depletion; however, the model calculations of ozone depletion between 1 and 0.3 mbar $(\sim 50$ and $60 \mathrm{~km})$ tend to be smaller than the ozone depletion observed with the Nimbus 7 SBUV instrument.

The positive ions produced by the solar protons form ion water clusters and, subsequently, $\mathrm{H}$ and $\mathrm{OH}$. Below $70 \mathrm{~km}$ most of the positive ions result in the formation of two $\mathrm{HO}_{x}$ species apiece. Above $75 \mathrm{~km}$ the $\mathrm{HO}_{x}$ produced per positive ion is somewhat less than 2 and is also strongly altitudedependent [Solomon et al., 1983b]. In this paper we are concerned with altitudes at and below $60 \mathrm{~km}$, and we assume that two $\mathrm{HO}_{x}$ species are produced per positive ion.

\section{Two-Dimensional Model Description}

The ion pair production was input into our twodimensional (2-D) photochemical model [Douglass et al., 1989], whose vertical range, equally spaced in log pressure, has been extended to be from the ground to approximately $90 \mathrm{~km}(0.0024 \mathrm{mbar})$ with about a $2-\mathrm{km}$ grid spacing and from $85^{\circ} \mathrm{S}$ to $85^{\circ} \mathrm{N}$ with a $10^{\circ}$ grid spacing. We used heating rates and temperatures from Rosenfield et al. [1987] in order to compute our background residual circulation. Since Rosenfield et al. [1987] indicate that questions remain concerning the quality of the temperature and ozone data and the accuracy of the radiative transfer scheme above $0.1 \mathrm{mbar}$ $(\sim 66 \mathrm{~km})$, we only show results from our model that are below 0.23 mbar $(\sim 60 \mathrm{~km})$. We consider the upper extent of our model (from 0.23 to 0.0024 mbar) to act as a sponge layer which nevertheless contains a reasonable simulation of the dynamics and photochemistry of the upper region.

The SPE production of 1.25 atomic $\mathrm{N}$ per ion pair and 2 $\mathrm{OH}$ per ion pair was input at geomagnetic latitudes above $60^{\circ}$. This corresponded to inputting the atomic $\mathrm{N}$ and $\mathrm{OH}$ in the 2-D model using weighting factors of 1.0 for model grid boxes centered on $\pm 85^{\circ}, 0.98$ for $\pm 75^{\circ}, 0.60$ for $\pm 65^{\circ}, 0.31$ for $\pm 55^{\circ}, 0.02$ for $\pm 45^{\circ}$, and 0.0 for all other latitudes [Jackman and Meade, 1988].

Major species $\mathrm{N}_{2}$ (78\% of the atmosphere) and $\mathrm{O}_{2}$ (21\% of the atmosphere) are calculated solving the hydrostatic equation using monthly average temperature fields from the National Meteorological Center (NMC) for 1000-0.4 mbar and CIRA (1978) above 0.4 mbar following Rosenfield et al. [1987]. The $\mathrm{CO}_{2}$ mixing ratio is set at $330 \mathrm{ppmv}$. The stratospheric and mesospheric $\mathrm{H}_{2} \mathrm{O}$ distribution is fixed to LIMS measurements where possible and set to LIMS measurements at 1.68 mbar for all altitudes above 1.68 mbar. Extrapolation of $\mathrm{H}_{2} \mathrm{O}$ values to latitudes south of $65^{\circ} \mathrm{S}$ was accomplished by using northern hemisphere data during a comparable season. LIMS $\mathrm{H}_{2} \mathrm{O}$ measurements extend for only 7 months, and thus seasonal reflection between hemispheres was used for the other 5 months (see Jackman et al. [1987] for further discussion). The tropospheric $\mathrm{H}_{2} \mathrm{O}$ concentrations are set to values from our previous 2-D model calculations [Guthrie et al., 1984] and are close to those of Newell et al. [1972]. Thirty-four minor species are calculated in the model, although not all of them are transported individually. Three groups of species are transported using the family approach: $\mathrm{O}_{x}\left(\mathrm{O}_{3} \mathrm{O}\left({ }^{1} D\right), \mathrm{O}\left({ }^{3} P\right)\right), N O_{y}$, not including $\mathrm{HNO}_{3},\left(\mathrm{~N}, \mathrm{NO}, \mathrm{NO}_{2}, \mathrm{NO}_{3}, \mathrm{HO}_{2} \mathrm{NO}_{2}, \mathrm{~N}_{2} \mathrm{O}_{5}\right.$, and 
TABLE 1. Lower Boundary Conditions for All Transported Species

\begin{tabular}{|c|c|c|c|}
\hline Species & $\begin{array}{l}\text { Type of Boundary } \\
\text { Condition }\end{array}$ & 1980 Value & 1972 Value \\
\hline $\mathrm{N}_{2} \mathrm{O}$ & mixing ratio (ppbv) & 300 & 300 \\
\hline $\mathrm{CH}_{4}$ & mixing ratio (ppmv) & 1.6 & 1.6 \\
\hline $\mathrm{CO}^{+}$ & mixing ratio (ppbv) & 100 & 100 \\
\hline $\mathbf{H}_{2}$ & mixing ratio (ppbv) & 500 & 500 \\
\hline $\mathrm{CH}_{3} \mathrm{OOH}$ & flux $\left(\mathrm{cm}^{-2} \mathrm{~s}^{-1}\right)$ & 0.0 & 0.0 \\
\hline $\mathrm{CH}_{3} \mathrm{Cl}$ & mixing ratio (pptv) & 700 & 700 \\
\hline $\mathrm{CH}_{3} \mathrm{CCl}_{3}$ & mixing ratio (pptv) & 100 & 100 \\
\hline $\mathrm{CCl}_{4}$ & mixing ratio (pptv) & 100 & 100 \\
\hline $\mathrm{CFCl}_{3}$ & mixing ratio (pptv) & 170 & 70 \\
\hline $\mathrm{CF}_{2} \mathrm{Cl}_{2}$ & mixing ratio (pptv) & 285 & 130 \\
\hline $\mathrm{O}_{x}$ & deposition velocity $\left(\mathrm{cm} \mathrm{s}^{-1}\right)$ & 0.1 & 0.1 \\
\hline $\mathrm{HNO}_{3}$ & mixing ratio (pptv) & 90 & 90 \\
\hline $\mathrm{NO}_{y}$ (not including $\mathrm{HNO}_{3}$ ) & mixing ratio (pptv) & 10 & 10 \\
\hline $\mathrm{Cl}_{x}$ & flux $\left(\mathrm{cm}^{-2} \mathrm{~s}^{-1}\right)$ & 0.0 & 0.0 \\
\hline
\end{tabular}

$\left.\mathrm{ClONO}_{2}\right)$, and $\mathrm{Cl}_{y}\left(\mathrm{Cl}, \mathrm{ClO}, \mathrm{HOCl}, \mathrm{HCl}\right.$, and $\left.\mathrm{ClONO}_{2}\right)$. Partitioning among the family members is done in the manner described by Douglass et al. [1989]. Other transported species include $\mathrm{HNO}_{3}, \mathrm{~N}_{2} \mathrm{O}, \mathrm{CH}_{4}, \mathrm{H}_{2}, \mathrm{CO}$, $\mathrm{CH}_{3} \mathrm{OOH}, \mathrm{CFCl}_{3}, \mathrm{CF}_{2} \mathrm{Cl}_{2}, \mathrm{CH}_{3} \mathrm{Cl}, \mathrm{CCl}_{4}$, and $\mathrm{CH}_{3} \mathrm{CCl}_{3}$. The $\mathrm{HO}_{x}\left(\mathrm{H}, \mathrm{OH}, \mathrm{HO}_{2}\right)$ species, $\mathrm{H}_{2} \mathrm{O}_{2}$, and the hydrocarbons $\mathrm{CH}_{3}, \mathrm{CH}_{3} \mathrm{O}, \mathrm{CH}_{3} \mathrm{O}_{2}, \mathrm{CH}_{2} \mathrm{O}$, and $\mathrm{CHO}$ are calculated using photochemical equilibrium assumptions.

The boundary conditions are given in Table 1 for the two model background cases used: (1) a simulation of year 1980 with $\sim 2.5 \mathrm{ppbv} \mathrm{Cl}_{x}$ input at the ground and (2) a simulation of year 1972 with $\sim 1.7 \mathrm{ppbv} \mathrm{Cl}_{x}$ input at the ground. Most reaction rates and photodissociation cross sections are taken from DeMore et al. [1987] and presented by Douglass et al. [1989]. Some reactions were added when the upper boundary was moved to $90 \mathrm{~km}$. The reactions added were $\mathrm{O}+\mathrm{O}$ $+\mathrm{M} \rightarrow \mathrm{O}_{2}+\mathrm{M}$ with $k=1.4 \times 10^{-33} \exp (408 / T) \mathrm{cm}^{6} \mathrm{~s}^{-1}$ from Hampson [1980], $\mathrm{N}+\mathrm{OH} \rightarrow \mathrm{NO}+\mathrm{H}$ with $k=5.0 \times$ $10^{-11} \mathrm{~cm}^{3} \mathrm{~s}^{-1}$ from DeMore et al. [1987], and $\mathrm{CO}_{2}+h \nu \rightarrow$ $\mathrm{CO}+\mathrm{O}$ with $J<220 \mathrm{~nm}$ from DeMore et al. [1987]. Another reaction which was included in the simulation but inadvertently left out of Table 2 of Douglass et al. [1989] was $\mathrm{OH}+$ $\mathrm{CH}_{3} \mathrm{CCl}_{3} \rightarrow 3(\mathrm{Cl})$ with $k=5.0 \times 10^{-12} \exp (-1800 / T) \mathrm{cm}^{3}$ $\mathrm{s}^{-1}$ from DeMore et al. [1987].

The 2-D model was run 20 years to a seasonally repeating steady state for the two model background cases, years 1980 and 1972. The model was then run for 23 years from 1963 through 1985 using the year 1980 background case. No SPEs were allowed to occur in 1985 so that the model had a chance to relax to its ambient state before the end of the model run. A closer look at the effect of the August 1972 SPE on the middle atmosphere used the 1972 background case. Several runs were completed for 1972, some for 60 days in which the output was analyzed every day and some for 360 days (1 model year) in which the output was analyzed every 10 days.

The solar cycle ultraviolet (UV) flux variation was not accounted for in any of our computer simulations. Some variation is expected in the background $\mathrm{NO}_{y}$ abundance because of the solar cycle UV flux variation. We do not include this UV change so that it is possible to analyze more easily the straightforward influence of solar protons.

\section{OdD Nitrogen $\left(\mathrm{NO}_{v}\right)$ VARIAbiLITy DUe to SPEs}

Odd nitrogen $\left(\mathrm{NO}_{y}=\mathrm{N}+\mathrm{NO}+\mathrm{NO}_{2}+\mathrm{NO}_{3}+\mathrm{HO}_{2} \mathrm{NO}_{2}\right.$ $+\mathrm{HNO}_{3}+2 \mathrm{~N}_{2} \mathrm{O}_{5}+\mathrm{ClONO}_{2}$ ), due to its lifetime of months, is of interest for any long-term stratospheric changes. We investigate $\mathrm{NO}_{y}$ at $75^{\circ} \mathrm{N}$ because of the large changes associated with SPEs at this high latitude. Figure $3 a$ illustrates the variability of $\mathrm{NO}_{y}$ at $1.7 \mathrm{mbar}(44 \mathrm{~km})$ and $75^{\circ} \mathrm{N}$ over the 23 -year period. Note that $\mathrm{NO}_{y}$ can vary dramatically after an SPE, especially after the August 1972 SPE. Generally, the $\mathrm{NO}_{y}$ values return to their ambient levels 2-6 months after the event, but after the August 1972 SPE the stratospheric $\mathrm{NO}_{y}$ values take about a year to return to their ambient levels.
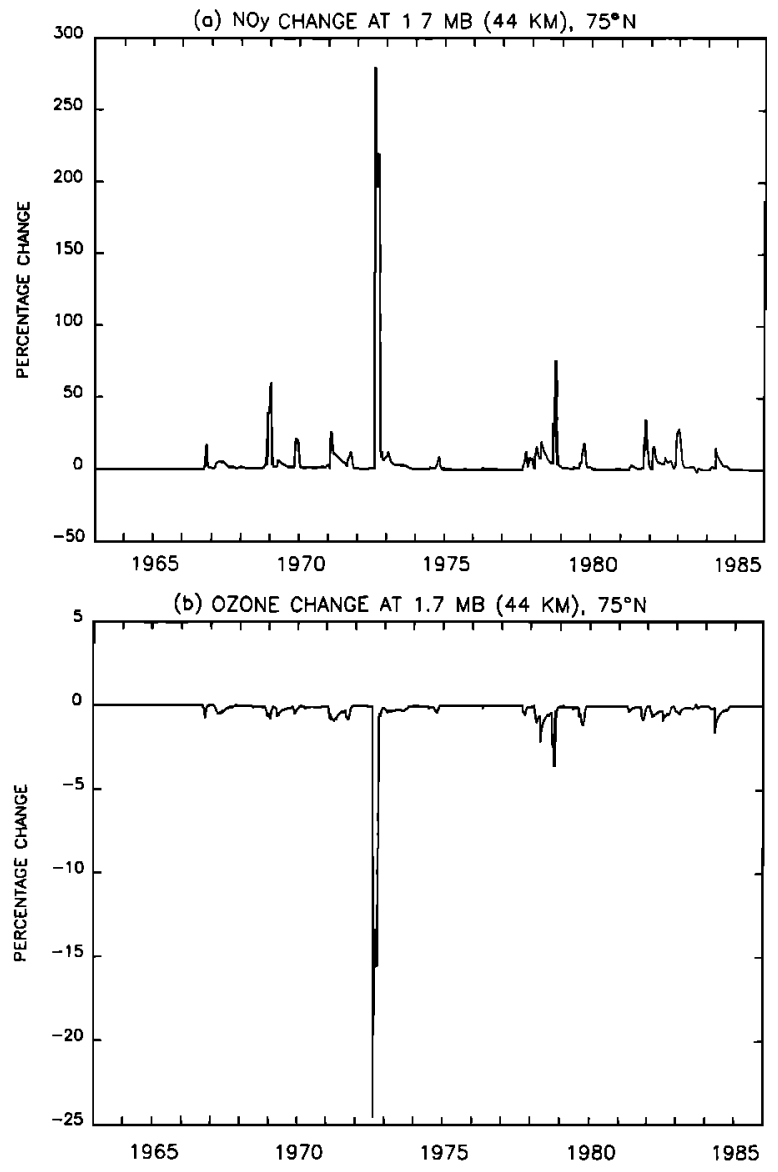

Fig. 3. Model-predicted (a) $\mathrm{NO}_{y}$ and $(b)$ ozone percentage change at $1.7 \mathrm{mbar}(44 \mathrm{~km})$ and $75^{\circ} \mathrm{N}$. 

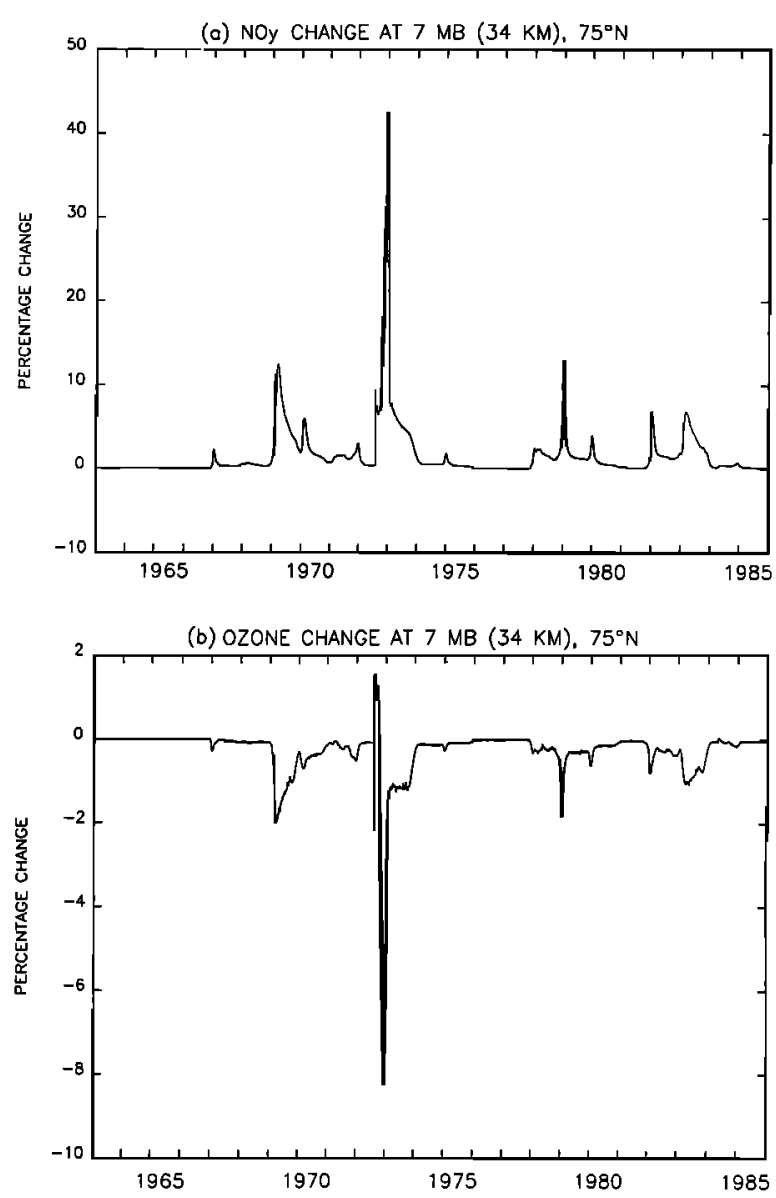

Fig. 4. Model predicted $(a) \mathrm{NO}_{y}$ and $(b)$ ozone percentage change at $7 \mathrm{mbar}(34 \mathrm{~km})$ and $75^{\circ} \mathrm{N}$.

The $\mathrm{NO}_{y}$ seems to be affected only by those SPEs which have an ion pair production over about 100 ion pairs $\mathrm{cm}^{-3}$ $\mathrm{s}^{-1}$ (see Figure $2 b$ ). The ambient $\mathrm{NO}_{y}$ amounts help determine the magnitude of the computed $\mathrm{NO}_{y}$ change at a certain level. These ambient $\mathrm{NO}_{y}$ amounts vary with season, being less in late winter and more in late summer. The same production rate of $\mathrm{N}$ atoms, adding, say, $2 \mathrm{ppbv}$ of $\mathrm{NO}_{y}$ to a 14 ppbv background at 4 mbar and $85^{\circ} \mathrm{N}$ in late summer will have less of an effect than the same production rate of $\mathrm{N}$ atoms, adding, say, 2 ppbv of $\mathrm{NO}_{y}$ to a 4-ppbv background at $4 \mathrm{mbar}$ and $85^{\circ} \mathrm{S}$ in late winter (see Jackman and Meade [1988] for further discussion). Some downflux of $\mathrm{NO}_{y}$ from the SPE's mesospheric production of $\mathrm{NO}_{y}$ is important during late fall, winter, and early spring and influences the amount of $\mathrm{NO}_{y}$ in the upper stratosphere.

Figure $4 a$ illustrates the behavior of $\mathrm{NO}_{y}$ at $34 \mathrm{~km}$. Figures $3 a$ and $4 a$, as well as our analysis of $\mathrm{NO}_{y}$ at other altitudes and latitudes, indicate that although the $\mathrm{NO}_{y}$ produced by SPEs over solar cycle time periods does not build up, it can be important at high latitudes on time scales of months to a year. This result is not surprising as only a small fraction of the annual odd nitrogen budget results from SPEs [Jackman et al., 1980]. Most of the annual production of odd nitrogen is a result of $\mathrm{N}_{2} \mathrm{O}$ oxidation and was computed by Jackman et al. [1987] to be $2.6 \times 10^{34} \mathrm{NO}_{y}$ molecules $\mathrm{yr}^{-1}$. Here we have a different ozone and $\mathrm{N}_{2} \mathrm{O}$ distribution (model computed rather than specified as by Jackman et al. [1987]) and compute the annual production of odd nitrogen as a result of

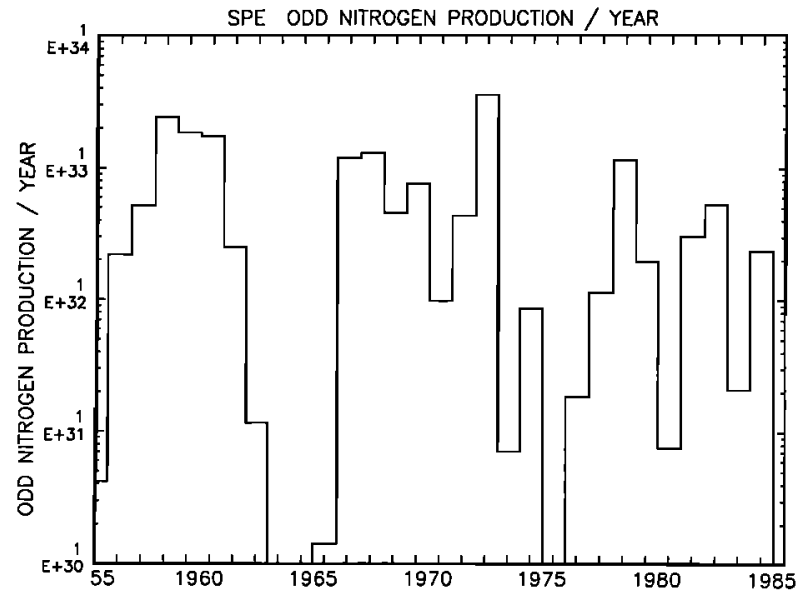

Fig. 5. Solar proton event (SPE) odd nitrogen production in molecules $\mathrm{yr}^{-1}$ for years 1955-1984.

$\mathrm{N}_{2} \mathrm{O}$ oxidation to be $2.9 \times 10^{34} \mathrm{NO}_{y}$ molecules $\mathrm{yr}^{-1}$. The largest production of $\mathrm{NO}_{y}$ molecules from SPEs was in the year 1972 at the level of $3.6 \times 10^{33} \mathrm{NO}_{y}$ molecules $\mathrm{yr}^{-1}$, only $12 \%$ of the $\mathrm{N}_{2} \mathrm{O}$ oxidation source. Since this SPE source is confined to high latitudes, we note that it is significantly larger than the yearly $\mathrm{N}_{2} \mathrm{O}$ oxidation source at latitudes greater than $50^{\circ}$, calculated to be $2.2 \times 10^{33} \mathrm{NO}_{y}$ molecules per $\mathrm{yr}^{-1}$. The production of odd nitrogen molecules from SPEs in other major SPE-active years is less than that computed for 1972 .

We show the annual production of odd nitrogen from SPEs in the middle atmosphere for the years 1955-1984 in Figure 5. The annual production for the years 1955-1962 is taken from Jackman et al. [1980], and the years 1963-1984 are taken from this study. The values for the stratosphere and mesosphere, separately and together, are given in Table 2. Clearly, there is a large variation in the annual addition of odd nitrogen from SPEs.

\section{Ozone VARIANCE DUe to SPEs}

The investigation of the long-term influence of SPEs on ozone is the primary purpose of this paper. We would like to answer the question: Do SPE-related changes in ozone need to be considered when investigating long-term variations of ozone? Figure $3 b$ illustrates the variability of ozone at 1.7 mbar (44 km) and $75^{\circ} \mathrm{N}$ over the 23-year period. In Figure $4 b$ we show the ozone at $7 \mathrm{mbar}(34 \mathrm{~km})$ and $75^{\circ} \mathrm{N}$. In general, the $\mathrm{NO}_{y}$ increase corresponds to an ozone decrease. Note, however, that ozone goes up during several days of 1972 at $7 \mathrm{mbar}$ (see Figure $4 b$ ). This is a result of self-healing due to ozone depletion above.

It is clear from Figures $3 b$ and $4 b$ that the largest changes in ozone in the stratosphere are connected with the August 1972 SPE. Because of this we have investigated the time period during and just after the August 1972 SPE in more detail. We first ran the model to steady state (20-year computer simulation) for the 1972 boundary conditions (see Table 1). Next we ran a base case for 60 and 360 days, with daily and 10-day interval outputs, respectively. Finally, we simulated the August 1972 SPE with the model (several times) over 60- and 360-day time periods. We found only small differences in the ozone depletion from the August 
TABLE 2. Odd Nitrogen Molecules Produced per Year in the Mesosphere, Stratosphere, and Both the Mesosphere and Stratosphere

\begin{tabular}{cccc}
\hline Year & $\begin{array}{c}\text { Mesospheric } \\
\text { Contribution }\end{array}$ & $\begin{array}{c}\text { Stratospheric } \\
\text { Contribution }\end{array}$ & $\begin{array}{c}\text { Total } \\
\text { Contribution }\end{array}$ \\
\hline 1955 & $3.24(+30)$ & $9.32(+29)$ & $4.17(+30)$ \\
1956 & $1.19(+32)$ & $1.00(+32)$ & $2.19(+32)$ \\
1957 & $4.64(+32)$ & $5.07(+31)$ & $5.15(+32)$ \\
1958 & $1.98(+33)$ & $4.38(+32)$ & $2.42(+33)$ \\
1959 & $1.42(+33)$ & $4.37(+32)$ & $1.86(+33)$ \\
1960 & $6.63(+32)$ & $1.08(+33)$ & $1.74(+33)$ \\
1961 & $1.40(+32)$ & $1.09(+32)$ & $2.49(+32)$ \\
1962 & $9.25(+30)$ & $2.30(+30)$ & $1.16(+31)$ \\
1963 & $6.56(+29)$ & $7.05(+28)$ & $7.26(+29)$ \\
1964 & $4.65(+29)$ & $1.26(+28)$ & $4.78(+29)$ \\
1965 & $3.89(+30)$ & $3.64(+29)$ & $1.42(+30)$ \\
1966 & $1.19(+33)$ & $1.44(+30)$ & $1.19(+33)$ \\
1967 & $1.29(+33)$ & $1.02(+31)$ & $1.30(+33)$ \\
1968 & $4.31(+32)$ & $2.54(+31)$ & $4.56(+32)$ \\
1969 & $7.56(+32)$ & $4.46(+31)$ & $7.60(+32)$ \\
1970 & $8.85(+31)$ & $9.44(+30)$ & $9.79(+31)$ \\
1971 & $3.85(+32)$ & $4.65(+31)$ & $4.32(+32)$ \\
1972 & $2.09(+33)$ & $1.46(+33)$ & $3.55(+33)$ \\
1973 & $5.18(+30)$ & $1.88(+30)$ & $7.06(+30)$ \\
1974 & $7.34(+31)$ & $1.24(+31)$ & $8.58(+31)$ \\
1975 & $6.10(+29)$ & $2.42(+29)$ & $8.52(+29)$ \\
1976 & $1.44(+31)$ & $4.09(+30)$ & $1.85(+31)$ \\
1977 & $9.19(+31)$ & $2.18(+31)$ & $1.14(+32)$ \\
1978 & $1.01(+33)$ & $1.46(+32)$ & $1.16(+33)$ \\
1979 & $1.58(+32)$ & $3.72(+31)$ & $1.95(+32)$ \\
1980 & $6.08(+30)$ & $1.46(+30)$ & $7.54(+30)$ \\
1981 & $2.59(+32)$ & $4.69(+31)$ & $3.06(+32)$ \\
1982 & $4.55(+32)$ & $7.65(+31)$ & $5.32(+32)$ \\
1983 & $1.80(+31)$ & $2.89(+30)$ & $2.09(+31)$ \\
1984 & $1.79(+32)$ & $5.68(+31)$ & $2.36(+32)$ \\
\hline & & &
\end{tabular}

${ }^{*}$ Read $3.24(+30)$ as $3.24 \times 10^{30}$

1972 SPE predicted by the model for conditions in 1980 ( $\sim 2.5$ ppbv $\mathrm{Cl}_{x}$ at the ground) and $1972\left(\sim 1.7 \mathrm{ppbv} \mathrm{Cl}_{x}\right.$ at the ground). The extra $\mathrm{Cl}_{x}$ for 1980 conditions was expected to tie up more $\mathrm{NO}_{y}$ into unreactive $\mathrm{ClONO}_{2}$ [Solomon et al., 1981], leading to a smaller ozone depletion from the SPEproduced $\mathrm{NO}_{y}$. Our 1980 condition computations show a couple of percent smaller ozone depletion than was indicated in our 1972 condition computations. These calculations imply that increases in atmospheric $\mathrm{Cl}_{x}$ close to $50 \%(1.7-2.5$ ppbv), at least for these levels of chlorine, cause relatively little change in the ozone response to SPEs.

We were fortunate to have Nimbus 4 backscattered ultraviolet (BUV) instrument ozone measurements during the August 1972 SPE. We compare our model output with a percentage difference plot which was constructed from a comparison of 1972 with 1970 BUV ozone data. These BUV comparison data (percentage ozone changes from 1970 to 1972) are given in Figures $6 a$ and $6 b$ for the latitude intervals $70^{\circ}-80^{\circ} \mathrm{N}$ and $50^{\circ}-60^{\circ} \mathrm{N}$ for days $214-274$ of year 1972 . The percentage change in modeled ozone as a result of the August 1972 SPE is given in Figures $7 a$ and $7 b$ for similar latitudes $\left(75^{\circ}\right.$ and $\left.55^{\circ} \mathrm{N}\right)$ and days $214-274$ of year 1972. Both the modeled and BUV ozone depletion are larger at $75^{\circ} \mathrm{N}$ (Figures $6 a$ and $7 a$ ) than at $55^{\circ} \mathrm{N}$ (Figures $6 b$ and $7 b$ ). The magnitude of the depletion observed in the BUV data set is fairly close to that predicted by the model computation. For example, about a 15-25\% maximum ozone depletion was observed between $70^{\circ}$ and $80^{\circ} \mathrm{N}$ (Figure $6 a$ ) and predicted at $75^{\circ} \mathrm{N}$ (Figure $7 a$ ), and about a 5-10\% maximum ozone
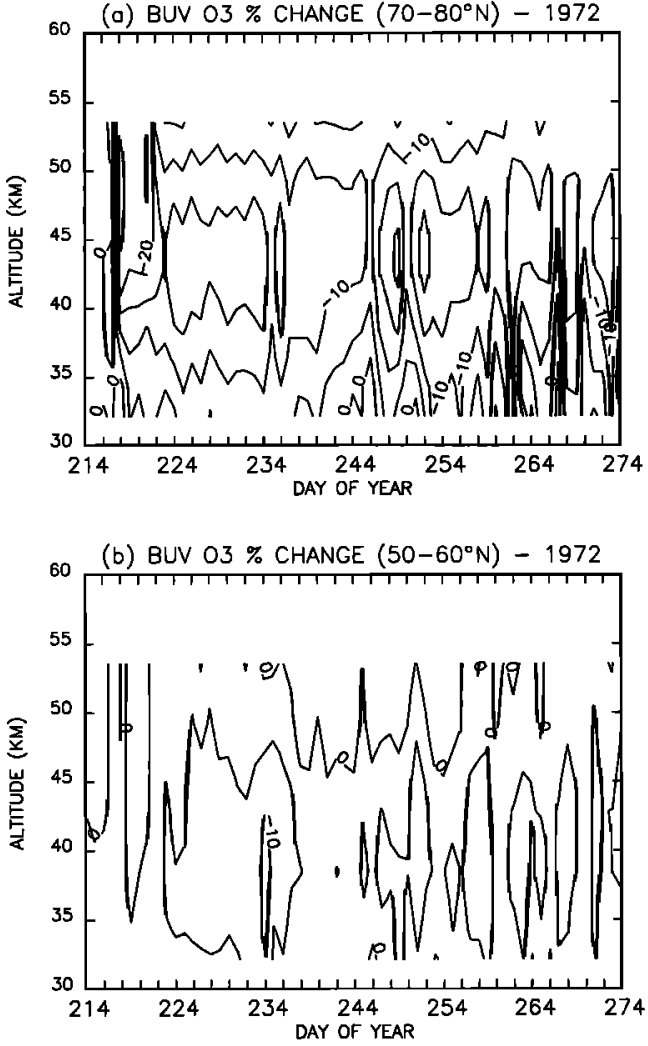

Fig. 6. Nimbus 4 BUV measured ozone percentage change as a function of day of year in 1972 for 60 days for $(a)$ the $70^{\circ}-80^{\circ} \mathrm{N}$ band and $(b)$ the $50^{\circ}-60^{\circ} \mathrm{N}$ band. The ozone change is a result of the August 1972 SPE and is given at the contour levels of $-30,-20$, $-15,-10,-5$, and $0 \%$.

depletion was observed between $50^{\circ}$ and $60^{\circ} \mathrm{N}$ (Figure $6 b$ ) and predicted at $55^{\circ} \mathrm{N}$ (Figure $7 b$ ). There are some differences between the modeled and BUV ozone depletion: (1) the BUV ozone depletion has more structure than seen in the 2-D model computation, indicating that the atmosphere is not yet uniformly zonally mixed from the initial ozone depletion which occurs in the geomagnetic polar cap region (greater than $60^{\circ}$ geomagnetic latitude) and (2) the BUV ozone depletion at higher altitudes (above $50 \mathrm{~km}$ ) is larger and persists for a longer period of time than indicated in the model predictions.

Figures $8 a$ and $8 b$ illustrate the modeled ozone depletion at $75^{\circ} \mathrm{S}$ and $55^{\circ} \mathrm{S}$, respectively. The model at $75^{\circ} \mathrm{S}$ shows over a $30 \%$ ozone depletion, while the model at $75^{\circ} \mathrm{N}$ indicates only about a $20 \%$ depletion. Also, the model at $75^{\circ} \mathrm{S}$ shows a large depletion near $60 \mathrm{~km}$ about a month after the August 1972 SPE. This depletion is caused by the downflux of the middle and upper mesospheric $\mathrm{NO}_{y}$, created by the August 1972 SPE, to the lower mesosphere. These lower mesospheric effects are almost gone by day 250 . The model at $55^{\circ} \mathrm{S}$ shows over a $20 \%$ ozone depletion about a month after the event, but the model at $55^{\circ} \mathrm{N}$ indicates between 5 and $10 \%$ depletion in the time period 20-60 days after the SPE. These results imply a large hemispheric difference in the level of ozone depletion.

Maeda and Heath [1980/1981] reported that the southern hemisphere did experience a larger ozone loss (more than a $40 \%$ reduction at $70^{\circ} \mathrm{S}$ ) than did the northern hemisphere (a $16.5 \%$ reduction at $70^{\circ} \mathrm{N}$ ), in fair agreement with our model 
(a) MODEL O3\% CHANGE AT $75^{\circ} \mathrm{N}-1972$

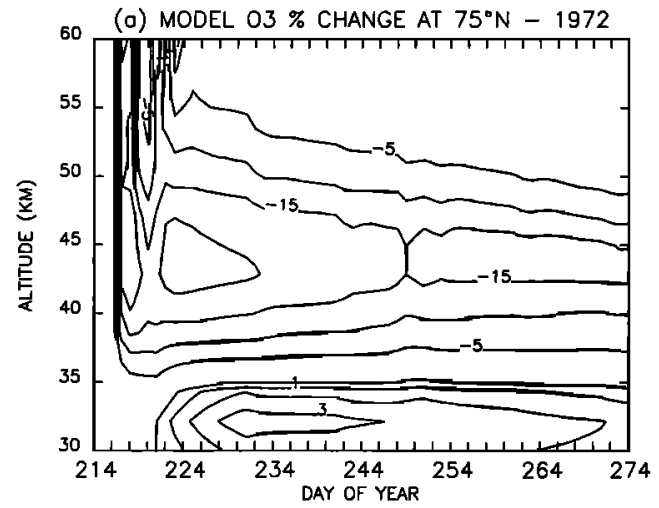

(b) MODEL O3\% CHANGE AT $55^{\circ} \mathrm{N}-1972$

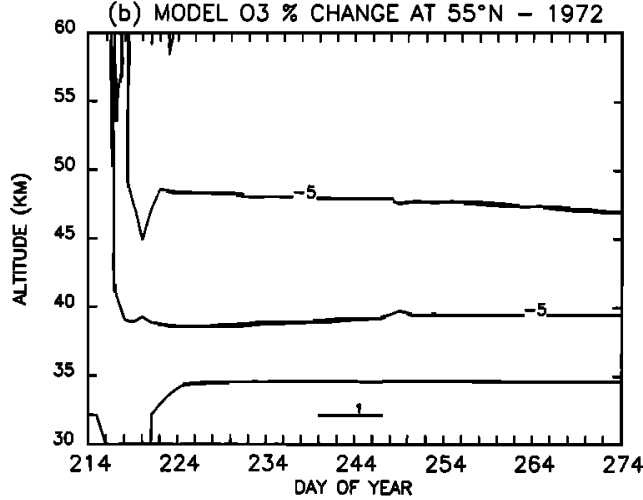

Fig. 7. Model predicted ozone percentage change as a function of day of year in 1972 for 60 days for $(a) 75^{\circ} \mathrm{N}$ and $(b) 55^{\circ} \mathrm{N}$. The ozone change is a result of the August 1972 SPE and is given at the contour levels of $-30,-20,-15,-10,-5,0,+1,+2$, and $+3 \%$.

predictions. We have now reanalyzed the southern hemisphere data for comparison with the northern hemisphere results just discussed. Because ozone is far more variable in the winter (southern hemisphere) than in the summer (northern hemisphere) and because only a few orbits of ozone data were available each day, we cannot create graphs for the southern hemisphere complementary to those of Figures $6 a$ and $6 b$. But if we compare weekly average ozone in zones $50^{\circ}-60^{\circ}$ and $60^{\circ}-70^{\circ}$ for the weeks immediately after the SPE with the weeks immediately before the SPE, we find that ozone between 2 and 10 mbar decreased more in the southern hemisphere than in the northern hemisphere but that the results are too uncertain to prove the existence of an interhemispheric difference.

This interhemispheric ozone depletion difference is caused by the different seasons which the two hemispheres are experiencing during and after the August 1972 SPE. SPEproduced $\mathrm{NO}_{y}$ in winter has a far greater effect on ambient $\mathrm{NO}_{y}$ amounts and therefore on ozone levels than does SPE-produced $\mathrm{NO}_{y}$ in summer. Not only are the background $\mathrm{NO}_{y}$ amounts less in winter, but the lifetime of $\mathrm{NO}_{y}$ is longer in winter than in summer, and the transport is directed downward in winter to regions of even longer lifetimes for $\mathrm{NO}_{y}$ (see discussion earlier and Jackman and Meade [1988] for more details of SPE effects on $\mathrm{NO}_{y}$ amounts).

A longer-term picture of the ozone depletion as well as the $\mathrm{NO}_{y}$ enhancement with time is shown in Figures 9 and 10 where the ozone and $\mathrm{NO}_{y}$ changes are given for a 1-year time period from day 210 in year 1972 to day 210 in year 1973 for latitudes $75^{\circ} \mathrm{N}$ and $75^{\circ} \mathrm{S}$. The output for Figures 9 and 10

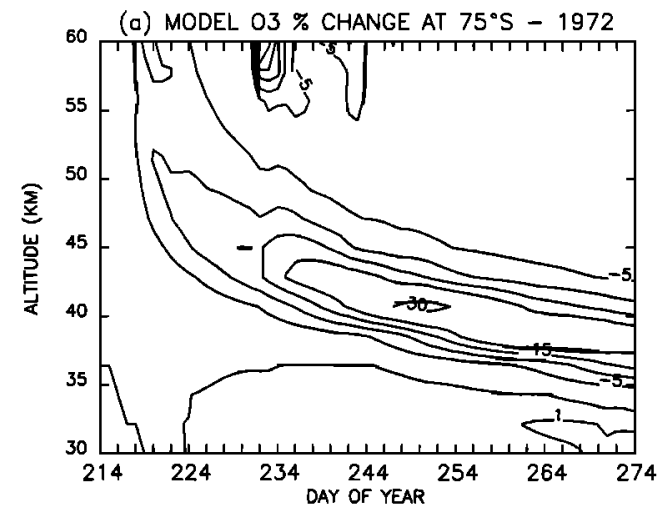

(b) MODEL O3 \% CHANGE AT $55^{\circ} \mathrm{S}-1972$

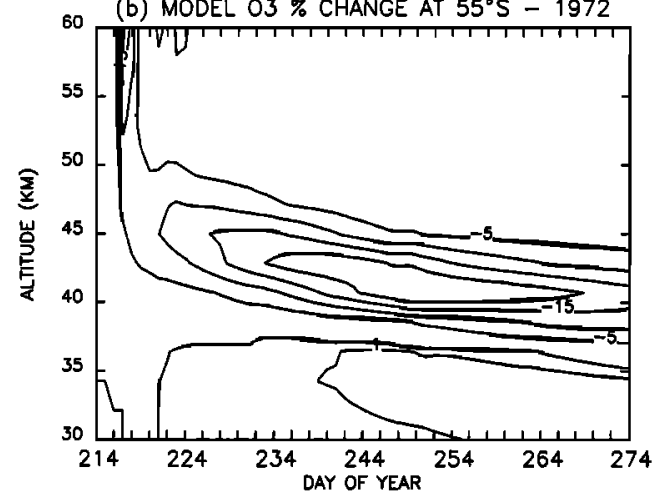

Fig. 8. Model predicted ozone percentage change as a function of day of year in 1972 for 60 days for $(a) 75^{\circ} S$ and $(b) 55^{\circ} S$. The ozone change is a result of the August 1972 SPE and is given at the contour levels of $-30,-20,-15,-10,-5,0,+1,+2$, and $+3 \%$.

was taken every 10 days rather than every day (used for Figures 7 and 8); thus some of the structure in the ozone depletion (see Figures $9 a$ and 10a) will not be quite the same as that observed in Figures $7 a$ and $8 a$. The ozone-depleted air is slowly transported downward to lower altitudes with time and gradually dissipates. The depletion is only as large as about $6 \%$ at pressure $10 \mathrm{mbar}(\sim 32 \mathrm{~km})$ by day 30 of year 1973 for both $75^{\circ} \mathrm{N}$ and $75^{\circ} \mathrm{S}$. Our computations suggest that the ozone depletion is simply a reflection of the $\mathrm{NO}_{y}$ enhancement (see Figures 9 and 10), even for months after the event. The $\mathrm{NO}_{y}$ increase is gradually diluted by transport of $\mathrm{NO}_{y}$ from lower latitudes, and the ozone depletion gradually disappears over several months to a year.

Total ozone change due to the August 1972 SPE is represented in Figure 11 for the time period days 210-360 in year 1972 . Ozone changes of slightly greater than $1 \%$ are observed at only the highest latitudes. The largest ozone depletion in the northern hemisphere occurs at $85^{\circ} \mathrm{N}$ during or slightly after the SPE, and the largest ozone depletion in the southern hemisphere occurs at $85^{\circ} \mathrm{S}$ about a month after the SPE, consistent with the interhemispheric differences in the ozone profiles (discussed above). The possibility of observing a change of this magnitude in the total column ozone data is remote because of the large daily fluctuations that accompany total ozone data at high latitudes.

\section{Sensitivity STUdies}

We carried out three sensitivity studies which will be discussed. The first sensitivity study was undertaken to 

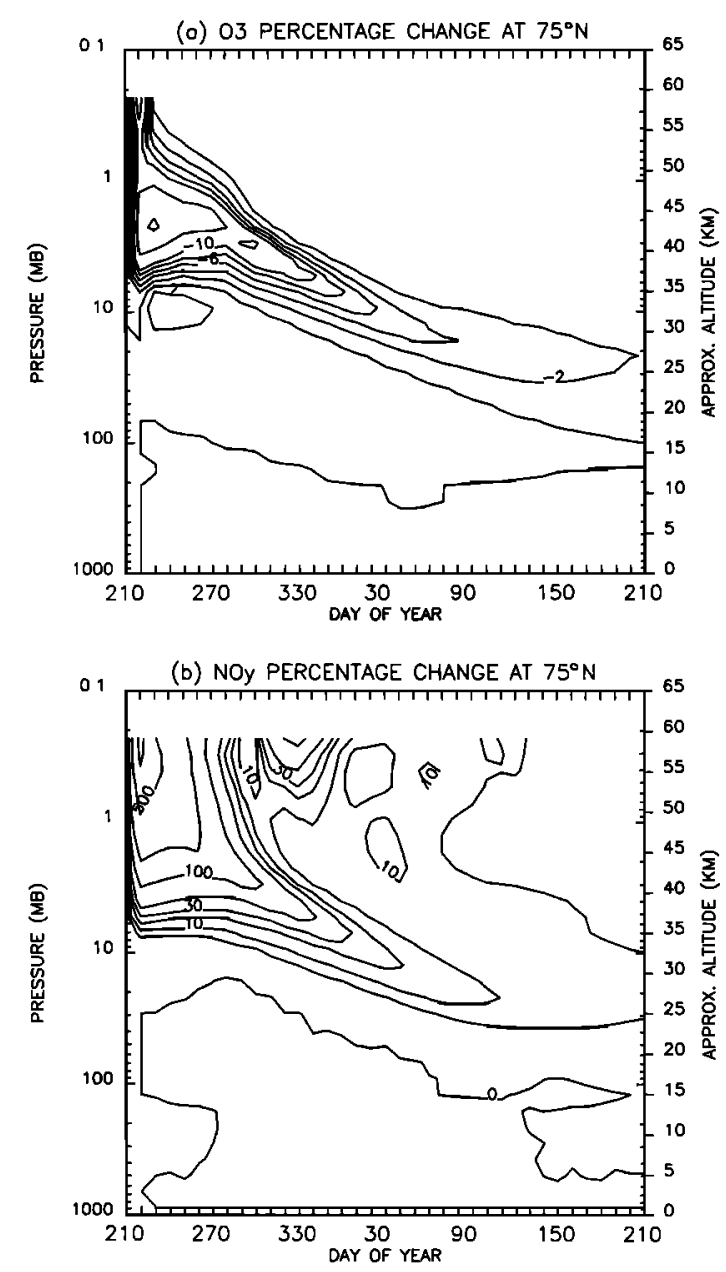

Fig. 9. Model predicted $(a)$ ozone and $(b) \mathrm{NO}_{y}$ percentage change as a function of day of year for $75^{\circ} \mathrm{N}$ for one year from day 210 of year 1972 to day 210 of year 1973. Both ozone and $\mathrm{NO}_{y}$ changes are a result of the August 1972 SPE. The ozone changes are given at the contour levels of $-30,-20,-15,-10,-8,-6,-4,-2$, 0 , and $+2 \%$, and the $\mathrm{NO}_{y}$ changes are given at the contour levels of $0,5,10,20,30,50,100,200,500$, and $1000 \%$.

determine the influence of $\mathrm{NO}_{x}$ produced above $66 \mathrm{~km}$ on $\mathrm{NO}_{y}$ and on $\mathrm{O}_{3}$ below $60 \mathrm{~km}$. We wanted to determine the influence of the middle and upper mesosphere, where the transport fields may be uncertain (see discussion in the section on two-dimensional model description) on the lower mesosphere and stratosphere. For this study we completed a model simulation of the August 1972 SPE for 1 year and input the $\mathrm{NO}_{x}$ produced from this event only at altitudes above $66 \mathrm{~km}$. When the results of this sensitivity study were compared with the results of our base model simulation for the August 1972 SPE, we found that (1) the percentage contribution from $\mathrm{NO}_{x}$ produced above $66 \mathrm{~km}$ to the $\mathrm{NO}_{y}$ change could be over 50\% at levels above 2 mbar for both hemispheres, (2) by 10 mbar the percentage contribution from the $\mathrm{NO}_{x}$ produced above $66 \mathrm{~km}$ to the $\mathrm{NO}_{y}$ change was less than $10 \%$ for both hemispheres, (3) the percentage contribution from $\mathrm{NO}_{x}$ produced above $66 \mathrm{~km}$ to $\mathrm{O}_{3}$ change was similar to that found for $\mathrm{NO}_{y}$ except with slightly smaller percentages represented. This implies that the large $\mathrm{O}_{3}$ depletions below $40 \mathrm{~km}(\sim 3 \mathrm{mbar})$, where $\mathrm{NO}_{x}$ chemistry is dominant, are predominantly caused by the $\mathrm{NO}_{y}$ created
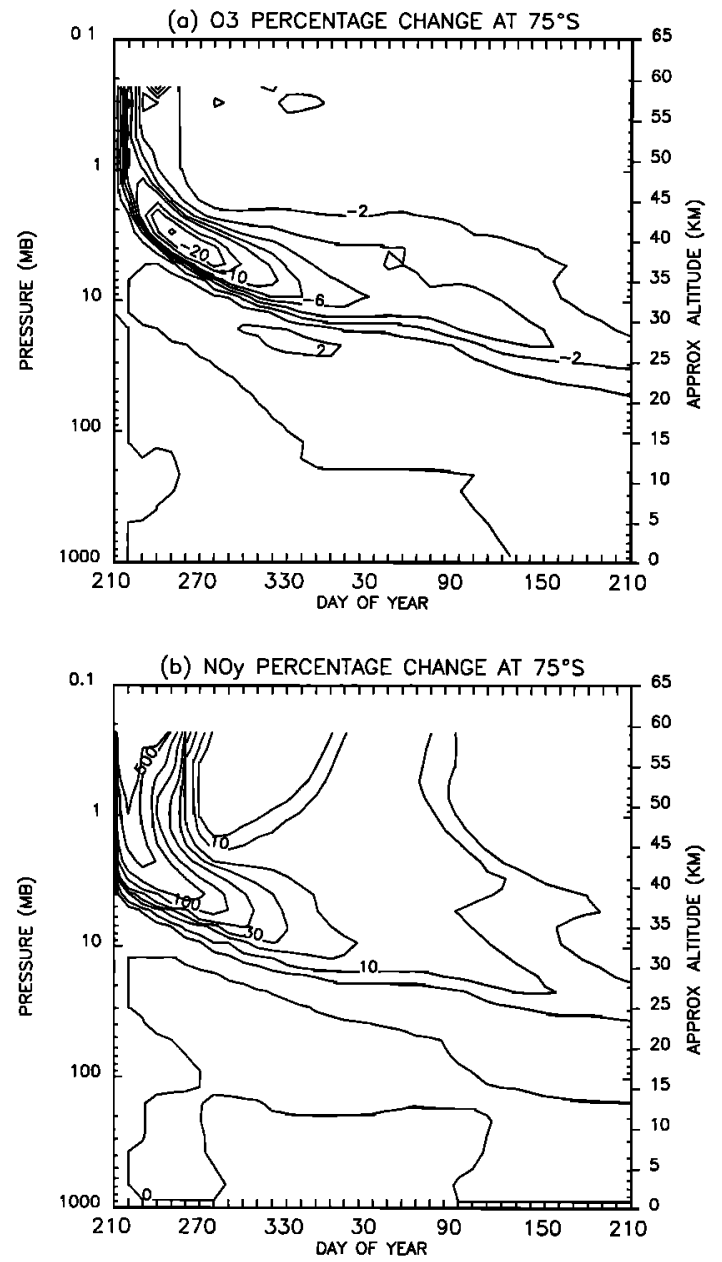

Fig. 10. Model predicted (a) ozone and (b) NO percentage change as a function of day of year for $75^{\circ} \mathrm{S}$ for 1 year from day 210 of year 1972 to day 210 of year 1973 . Both ozone and $\mathrm{NO}_{y}$ changes are a result of the August 1972 SPE. The ozone changes are given at the contour levels of $-20,-15,-10,-8,-6,-4,-2,0$ and $+2 \%$, and the $\mathrm{NO}_{y}$ changes are given at the contour levels of $0,5,10,20$, $30,50,100,200,500$, and $1000 \%$.

below $66 \mathrm{~km}$, where the 2-D model results are probably most reliable.

Model computations indicate fairly good agreement with ozone data for the SPE-induced ozone depletion caused by $\mathrm{NO}_{y}$ species connected with the August 1972 SPE. One difference that needs to be investigated is that the BUV ozone depletion at higher altitudes (above $50 \mathrm{~km}$ ) is larger and persists for a longer period of time than indicated in the model predictions. Two sensitivity studies were proposed to investigate this difference between model predictions and observations and are discussed below.

It is possible that in our model some atmospheric constituents are being transported from the upper mesosphere or stratosphere to the lower mesosphere but that this is not happening in the Earth's atmosphere. We investigate this concern with a sensitivity study in which no winds or diffusion are allowed in the model. This model experiment is totally unrealistic; however, it does illustrate the influence of transport on our results. The model results from this sensitivity study for the northern hemisphere are very similar to our model results presented in Figure 7. We do find, how- 


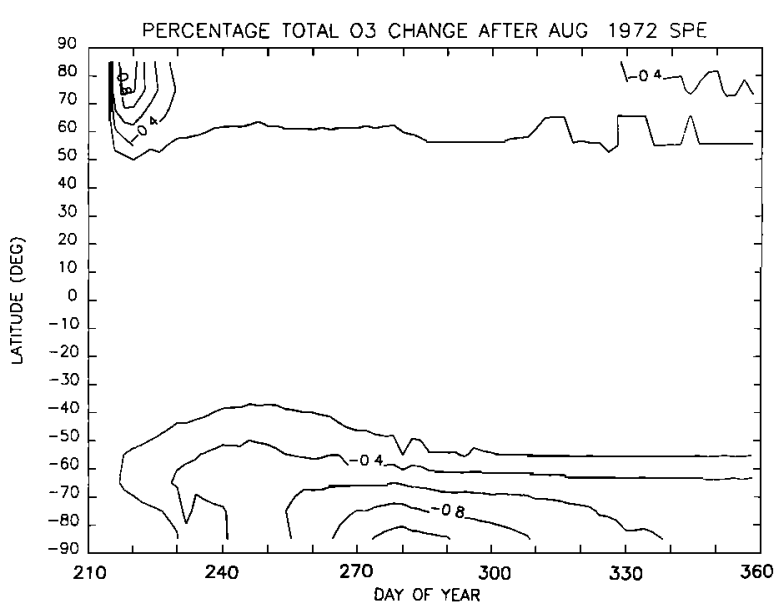

Fig. 11. Model predicted total ozone percentage change as a function of day of year for 1 year from day 210 of year 1972 to day 210 of year 1973. Contour levels represented are $-1,-0.8,-0.6$, -0.4 , and $-0.2 \%$.

ever, that the ozone-depleted air in this model experiment is not being transported to lower altitudes in the northern hemisphere as indicated in Figures 9 and 10. Model results in this sensitivity study for the southern hemisphere differ somewhat from our model results presented in Figure 8. Transport is very important in the 60 days presented for $55^{\circ}$ and $75^{\circ} \mathrm{S}$. The large ozone depletion observed in Figure $8 b$ is a result of $\mathrm{NO}_{y}$ transport; thus with no winds or diffusion the ozone depletion is predicted to be only between 5 and $10 \%$, and not the $30 \%$ presented in Figure $8 b$. The depletion at $75^{\circ} \mathrm{S}$ is about the same in this sensitivity study than shown in Figure $8 a$.

It is equally likely that in our model some atmospheric constituents are not being transported from the upper mesosphere or stratosphere to the lower mesosphere but that this is happening in the Earth's atmosphere. We investigate this concern with a sensitivity study in which the vertical diffusion is increased by a factor of 20 from 10 to 1 mbar (increasing from $2 \times 10^{3}$ to $4 \times 10^{4} \mathrm{~cm}^{2} \mathrm{~s}^{-1}$ ) with a constant value of $4 \times 10^{4} \mathrm{~cm}^{2} \mathrm{~s}^{-1}$ for altitudes above $1 \mathrm{mbar}$. Again, the values in the northern hemisphere are similar in this sensitivity study when compared to the base case. Less ozone depletion was predicted in this sensitivity study than observed in the base case for the southern hemisphere, however, the differences between the two studies are small.

Both sensitivity studies gave a smaller ozone depletion in the lower mesosphere than was observed in the data, the same as indicated in our base model simulation. These two sensitivity studies do not span all possible uncertainties in our 2-D model, but they do represent two extreme computations which indicate that it may be difficult to resolve easily the model-observation disagreement in the lower mesosphere. This disagreement between model predictions and satellite observations may be related to the ozone depletion problem noted earlier and discussed by Jackman and $\mathrm{Mc}$ Peters [1985]. They showed that model computations of ozone depletion in the lower mesosphere/upper stratosphere were less than indicated in the observations of ozone depletion by the Nimbus 7 SBUV instrument.

This model prediction problem may also be related to the classical problem that models tend to have in predicting ozone amounts in the upper stratosphere. Models tend to predict less ozone than observed or, equivalently, models constrained by observations predict more ozone loss than production in the ozone photochemical region which is located in the upper stratosphere at the low to middle latitudes [e.g., Wofsy, 1978; Butler, 1978; Frederick et al., 1978; Johnston and Podolske, 1978; Jackman et al., 1986; Natarajan and Callis, 1989; McElroy and Salawitch, 1989]. This discrepancy implies that we have something missing or incorrect in our photochemical description of the upper stratosphere; for instance, there could be a missing important reaction, an incorrect photodissociation or reaction rate, a missing important species, a combination of the above, or perhaps some other model simulation problem. Future observations of ozone depletion and $\mathrm{NO}_{y}$ or $\mathrm{HO}_{x}$ enhancements during SPEs may help in the resolution of this model-observation disagreement.

\section{Antarctic Nitrate Deposition}

The deposition of trace molecules in the surface ice sheet in both the northern and southern hemisphere is an intriguing problem. The southern hemisphere ice cores are characterized by large spikes in the nitrate $\left(\mathrm{NO}_{3}{ }^{-}\right)$concentration. These spikes could come from any of a variety of terrestrial and extraterrestrial sources [see Zeller and Parker, 1981, pp. 896-897]. Zeller et al. [1986] have indicted that the August 1972 SPE is observable in the nitrate deposition data. Earlier calculations [Jackman and McPeters, 1987] showed that enough $\mathrm{NO}_{y}$ was produced in the August 1972 SPE to possibly generate a detectable signal in the ice core. In this study we propose a viable mechanism for communicating enhanced amounts of stratospheric $\mathrm{NO}_{y}$ to the ground and further investigate the possibility of the August 1972 SPE event being observed in the Antarctic ice cores.

The mechanism and model studies are described in detail in the appendix. The mechanism requires the heterogeneous processes that are important in the formation of the Antarctic ozone hole. Basically, the $\mathrm{NO}_{y}$ produced by SPEs is transported downward to the lower stratosphere, removed from the gas phase by heterogeneous processes, and then precipitated into the troposphere and subsequently to the ground.

Performing model studies and then invoking the maximum possible ice deposition does not provide for an $\mathrm{NO}_{y}$ enhancement in the ice core that agrees with the observations of Zeller et al. [1986]. The maximum $\mathrm{NO}_{y}$ enhancement that is calculated is $1.6 \times 10^{15}$ molecules $\mathrm{cm}^{-2}$ at $75^{\circ} \mathrm{S}$, which is a $10.6 \%$ increase in $\mathrm{NO}_{y}$ above the model background. If the entire amount was transported to the ground within 1 month, the nitrate flux could be as large as $1.6 \mathrm{mg} \mathrm{NO}_{3}^{-} \mathrm{m}^{-2}$ month ${ }^{-1}$, in reasonable agreement with Zeller et al. [1986]. However, the nitrate maximum can only be $10.6 \%$ above the background and enhancements measured by Zeller et al. are $400 \%$ above background. Therefore our model suggests that the correlation of the spike with the August 1972 SPE is fortuitous and that the spike has a different origin.

A complementary study of the effects of solar cycle variations on stratospheric odd nitrogen and the possible geochemical implications in Antarctic nitrate flux was recently published by Legrand et al. [1989]. Legrand et al. [1989] studied the effect of solar cycle variations in ultraviolet radiation, thermospheric and mesospheric $\mathrm{NO}_{v}$ down- 
ward transport, and galactic cosmic rays on stratospheric $\mathrm{NO}_{y}$. They concluded that the net solar cycle changes in stratospheric $\mathrm{NO}_{y}$ are fairly modest (3-7\%) and that these changes are not sufficient to account for the solar cycle variation in Antarctic nitrate flux indicated by Zeller and Parker [1981].

We suggest that the solar cycle variation in nitrate flux [Zeller and Parker, 1981] and the spike in 1972 [Zeller et al., 1986] are perhaps indications of other atmospheric effects, such as cold temperatures in the lower stratosphere or tropospheric meteorological variation in the Antarctic.

\section{ConClusions}

It would be useful to compare these detailed studies with another large SPE similar in magnitude to the August 1972 SPE, perhaps one that occurs during the current solar active period. Since $\mathrm{NO}_{y}$ constituents are responsible for most of the ozone loss in the stratosphere [Jackman et al., 1986], this type of comparison is useful for further validation of $\mathrm{NO}_{y}$. ozone-related photochemistry.

Our model computations indicate that $\mathrm{NO}_{y}$ will not be substantially changed over a solar cycle by SPEs. Significant SPEs last only 1-5 days, tend to occur near solar maximum, and are typically months to years apart; thus the $\mathrm{NO}_{y}$ produced by SPEs does not, in general, build up. The $\mathrm{NO}_{y}$ changes caused by the SPEs are mainly at high latitudes and are on time scales of several months (most SPEs) to a year (August $1972 \mathrm{SPE}$ ), after which $\mathrm{NO}_{y}$ relaxes to its ambient levels. Fractional ozone changes are even smaller than the fractional $\mathrm{NO}_{y}$ changes and are significant only for the August 1972 SPE. Ozone, like $\mathrm{NO}_{y}$, returns to its ambient levels on time scales of several months to a year.

We presented a mechanism whereby $\mathrm{NO}_{y}$ enhancements in the stratosphere can be communicated to the ground. Our computations of the SPE-related increase in the stratospheric $\mathrm{NO}_{y}$ abundance indicated that the correlation between the huge spikes in nitrate flux data and major SPEs should probably be regarded as fortuitous.

\section{Appendix: Antarctic Nitrate Deposition}

Episodic spikes of nitrate in Arctic and Antarctic ice cores have been attributed to a variety of sources ranging from biological fixation, to supernovae, to solar activity [Zeller and Parker, 1981]. A major problem with the deposition of reactive stratospheric nitrogen compounds in the Antarctic ice pack has been the lack of any viable mechanism to communicate stratospheric air to the troposphere and subsequently to the surface on the necessary time scales. Zeller et al. [1986] show a nitrate peak 4 months after the 1972 SPE and attribute the peak to the SPE. In this appendix we propose a mechanism based on the 1987 Antarctic Airborne Ozone Experiment (AAOE) observations. Then, using the model, we investigate the possibility that the peak is caused by the SPE.

\section{Communication Mechanism}

The AAOE data revealed that the wintertime polar vortex is isolated from the rest of the hemisphere and contains very low values of $\mathrm{N}_{2} \mathrm{O}$ [e.g., Loewenstein et al., 1989]. The values of $\mathrm{N}_{2} \mathrm{O}$ within the vortex are approximately one half of the values found just outside the vortex. These low values within the vortex are typical of higher altitudes and are an indication that significant subsidence has taken place during the polar night. The AAOE results suggest that there is a downward displacement of polar air of the order of $5-10 \mathrm{~km}$ in the lower stratosphere. Qualitatively similar results have been found in the recent Airborne Arctic Stratospheric Expedition.

These large vertical displacements could be the first step in moving SPE-generated $\mathrm{NO}_{y}$ enhancements toward the ground. However, there is no indication that this downward motion would move the $\mathrm{NO}_{y}$ out of the stratosphere and into the troposphere. Therefore other steps are needed if the $\mathrm{NO}_{y}$ is to get to the ground.

The same heterogeneous mechanisms that are responsible for the formation of the Antarctic ozone hole can provide the next step. The current understanding of this mechanism is the formation of large water particles that scavenge out the reactive nitrogen compounds. These particles then precipitate out of the lower stratosphere, leaving the lower stratosphere depleted in reactive nitrogen and enhanced in reactive chlorine. The formation of water clouds in the stratosphere requires very low temperatures.

The AAOE data, therefore, suggest that the downward motion of $\mathrm{NO}_{y}$-rich air, followed by the precipitation of $\mathrm{NO}_{y}$-rich particles to the troposphere, followed by deposition of nitrate containing ice at the surface, could communicate the SPE event to the ground. The mechanism would be active in winter and spring and should work on the time scale of months. Of course, this mechanism would move the background $\mathrm{NO}_{y}$ as well as any SPE enhancement.

Given the above mechanism, there are several implications on nitrate deposition in the polar ice caps:

1. Temperatures in the northern hemisphere winter polar vortex are warmer than in the southern hemisphere. The temperatures do not regularly get cold enough to form water droplets, and there is no precipitation of nitrate-enriched air out of the stratosphere. Therefore spikes of extraterrestrial origin are not expected in the northern hemisphere.

2. Given the time scales of months for the existence of SPE-enhanced air, the effect of any particular SPE on ice cap deposition would be a strong function of the season in which the SPE occurred. For instance, the mechanism for downward displacement and precipitation would not occur during the summer, and an SPE in January would go largely unnoticed in the southern hemisphere ice cores.

3. The mechanism depends strongly on temperature and water vapor concentrations.

4. The spikes in the ice core may be entirely of terrestrial origin and simply markers of atmospheric processes (e.g., low stratospheric temperatures leading to cloud formation).

Given these possibilities, it is worth noting that $\mathbf{3 0}$ and $\mathbf{5 0}$ mbar temperatures during austral spring in 1972 at the south pole were the coldest observed prior to the 1980 s and the formation of the ozone hole [Trenberth and Olson, 1989]. Therefore the 1972 ice core nitrate maximum could be related to these cold temperatures. However, other cold seasons and the very cold temperatures seen in the 1980s do not obviously correlate with nitrate spikes. Any relation of the nitrate spikes to stratospheric activity is not straightforward, and careful analysis of tropospheric and stratospheric meteorology is needed to understand their origin. 


\section{Model Studies}

It is not possible to model fully the above mechanism within the current framework of the 2-D model because of the lack of heterogeneous (cloud) chemistry. However, the model transport fields can be altered to give a credible simulation of the AAOE observations. Then the maximum possible enhancement that the SPE could produce can be estimated. This section presents results from such experiments and, also, experiments that investigate the sensitivity of the results to the ion pair production by solar protons.

The model used in this study differs from the one used by Jackman and McPeters [1987]. Therefore we first investigate what the base model predicts about nitrate deposition. The model shows that the August 1972 SPE has enhanced the atmosphere in the year past the event between the ground and $10 \mathrm{mbar}$ by a maximum of $4.4 \times 10^{14} \mathrm{NO}_{y}$ molecules $\mathrm{cm}^{-2}$ (about a $3.5 \%$ increase) at $75^{\circ} \mathrm{S}$. It is reasonable to assume that only a small fraction of the $\mathrm{NO}_{y}$ enhancement above 10 mbar will make it to the ground after a year past the event, and thus we ignore this upper stratospheric (above 10 mbar) component of the $\mathrm{NO}_{y}$ enhancement. The increase in $\mathrm{NO}_{y}$ between the ground and 10 mbar as a result of the August 1972 SPE corresponds to a maximum deposition of about $0.45 \mathrm{mg} \mathrm{NO}{ }_{3}^{-} \mathrm{m}^{-2}$ month $^{-1}$ (assuming it is all deposited in a month). This can be compared to a value of approximately $1.5 \mathrm{mg} \mathrm{NO} \mathrm{m}^{-} \mathrm{m}^{-2}$ month $^{-1}$ above background from Zeller et al. [1986].

By setting the horizontal diffusion $\left(K_{y y}\right)$ to zero for latitudes of $\pm 65^{\circ}, \pm 75^{\circ}$, and $\pm 85^{\circ}$, it is possible to simulate the vortex isolation and downward motion observed during AAOE. This yields significantly more $\mathrm{NO}_{y}$ below $10 \mathrm{mbar}$ in the year following the SPE event. The enhancement is $1.6 \times$ $10^{15} \mathrm{NO}_{y}$ molecules $\mathrm{cm}^{-2}$ (about a $10.6 \%$ increase) at $75^{\circ} \mathrm{S}$. With heterogeneous processes it is reasonable to assume that the entire signal can be transported to the ground. Therefore the nitrate flux could be as large as $1.6 \mathrm{mg} \mathrm{NO}_{3}^{-}$ $\mathrm{m}^{-2}$ month $^{-1}$ (assuming it is all deposited in a month), which is in reasonable agreement with the observations of Zeller et al. [1986]. This computation pushes the $\mathrm{NO}_{y}$ enhancement of the ground nitrate flux to the limit.

The denitrification of lower stratospheric air by clouds would not act just on the SPE-enhanced $\mathrm{NO}_{y}$ but also on the background $\mathrm{NO}_{y}$. Even with the reduced $K_{y y}$ the $\mathrm{NO}_{y}$ increase due to the August 1972 event is only $10.6 \%$ above background. The enhancements of nitrate observed by Zeller et al. [1986] are $400 \%$ above background. Therefore our model suggests that the relationship of the spike with the August 1972 SPE is fortuitous.

It is also possible that errors exist in the specification of the $\mathrm{N}$ production by ion pairs. Laird et al. [1988] have argued that Legrand and Delmas [1986] did not observe a solar signal in the nitrate data because they did not take into account the possibility that SPEs produce more than $1.25 \mathrm{~N}$ atoms per ion pair. They discuss the possibility that SPEproduced $\mathrm{N}_{2}^{+}$constituents will form water clusters and then nitrate in water clusters. Other studies have indicated that $\mathrm{N}_{2}^{+}$will likely end up as $\mathrm{O}_{2}^{+}$first and eventually a water cluster [Frederick, 1976; Solomon et al., 1981] and not affect the $\mathrm{NO}_{y}$ abundance. Jackman et al. [1979] concluded that production rates larger than $1.5 \mathrm{NO}_{y}$ per ion pair in the stratosphere are difficult to justify.

We have performed a study to investigate if a larger production of $\mathrm{NO}_{y}$ per ion pair is reasonable. About the only possibility for $\mathrm{N}_{2}^{+}$to affect $\mathrm{NO}_{y}$ directly in the stratosphere is through a dissociative recombination with an electron with the resultant formation of two $\mathrm{N}$ atoms. The reaction $\mathrm{N}_{2}^{+}+$ $e^{-} \rightarrow \mathrm{N}^{*}+\mathrm{N}$ has a rate of $k_{1}=3 \times 10^{-7}(T / 300)^{-0.2} \mathrm{~cm}^{3}$ $\mathrm{s}^{-1}$ and the charge exchange reaction $\mathrm{N}_{2}^{+}+\mathrm{O}_{2} \rightarrow \mathrm{O}_{2}^{+}+\mathrm{N}_{2}$ has a rate of $k_{2}=2 \times 10^{-10} \mathrm{~cm}^{3} \mathrm{~s}^{-1}$ (both rates taken from Whitten and Poppoff $[1971$, p. 251]). The August 1972 SPE was the largest in the past 22 years, with electron densities computed to be between $10^{4}$ and $10^{5} \mathrm{~cm}^{-3} \mathrm{~s}^{-1}$ near $50 \mathrm{~km}$ [Banks, 1979]. At $50 \mathrm{~km}$ the $\mathrm{O}_{2}$ number density is $5.6 \times 10^{16}$ $\mathrm{cm}^{-3}$, and the temperature is about $260 \mathrm{~K}$. We compare the two rates for $\mathrm{N}_{2}^{+}$loss at $50 \mathrm{~km}$ by computing $k_{1} e^{-}=0.031$ $\mathrm{s}^{-1}$, assuming $e^{-}=10^{5} \mathrm{~cm}^{-3}$, an upper limit, and $k_{2} \mathrm{O}_{2}=$ $1.1 \times 10^{7} \mathrm{~s}^{-1}$. Clearly, the charge exchange reaction is several orders of magnitude faster than recombination for loss of $\mathrm{N}_{2}^{+}$at $50 \mathrm{~km}$. At lower altitudes the charge exchange is even more dominant. These calculations indicate that $\mathrm{N}_{2}^{+}$ will likely end up as $\mathrm{O}_{2}^{+}$and eventually a water cluster through $\mathrm{O}_{4}^{+}$to $\mathrm{O}_{2}^{+} \cdot \mathrm{H}_{2} \mathrm{O}$ and not affect the $\mathrm{NO}_{y}$ abundance, which is in agreement with the conclusions of Frederick [1976] and Solomon et al. [1981].

We did complete a sensitivity study in which some extra production of $\mathrm{N}$ atoms from $\mathrm{N}_{2}^{+}$recombination was input for the August 1972 SPE. For this model experiment we assume an $\mathrm{NO}_{y}$ production of $2.5 \mathrm{~N}$ atoms per ion pair (similar to that suggested by Laird et al. [1988]). This gave an $\mathrm{NO}_{y}$ enhancement between the ground and $10 \mathrm{mbar}$ of $8.7 \times 10^{14}$ $\mathrm{NO}_{y}$ molecules $\mathrm{cm}^{-2}$ at $75^{\circ} \mathrm{S}$, which translates into a maximum deposition of about $0.88 \mathrm{mg} \mathrm{NO}{ }_{3}^{-} \mathrm{m}^{-2}$ month $^{-1}$ (assuming it is all deposited in a month). This nitrate deposition is still less than that observed by Zeller et al. [1986]. We found that the ozone depletion predicted from this model calculation was somewhat higher than indicated in the BUV data for the northern hemisphere. At $75^{\circ} \mathrm{N}$ the maximum ozone decrease was computed to be $25-30 \%$, compared to the $15-25 \%$ observed, and at $55^{\circ} \mathrm{N}$ the ozone decrease was computed to be $10-15 \%$, compared to the $5-10 \%$ observed. We conclude from this study that a production of $2.5 \mathrm{~N}$ atoms per ion pair is probably too large.

Acknowledgments. The authors would like to thank Thomas $\mathrm{P}$. Armstrong (University of Kansas) for sending solar proton data that were used in the ion pair production computations for this paper. We would like to acknowledge Sushil Chandra of NASA Goddard Space Flight Center for useful comments on an earlier version of this manuscript. We thank Richard S. Stolarski of NASA Goddard Space Flight Center for helpful discussions concerning this research. Finally, we thank Linwood B. Callis of NASA/Langley Research Center and another anonymous reviewer for constructive comments on this manuscript. A.R.D. is a Universities Space Research Association Resident Associate.

\section{REFERENCES}

Armstrong, T. P., C. Brundardt, and J. E. Meyer, Satellite observations of interplanetary and polar cap solar particle fluxes from 1963 to the present, in Weather and Climate Response to Solar Variations, edited by B. M. McCormac, pp. 71-79, Colorado Associated University Press, Boulder, 1983.

Banks, P. M., Joule heating in the high-latitude mesosphere, $J$. Geophys. Res., 84, 6709-6712, 1979.

Butler, D. M., The uncertainty in ozone calculations by a stratospheric photochemistry model, Geophys. Res. Lett., 5, 769-772, 1978. 
Crutzen, P. J., I. S. A. Isaksen, and G. C. Reid, Solar proton events: Stratospheric sources of nitric oxide, Science, 189, 457-458, 1975.

DeMore, W. B., J. J. Margitan, M. J. Molina, R. T. Watson, D. M. Golden, R. F. Hampson, M. J. Kurylo, C. J. Howard, and A. R. Ravishankara, Chemical kinetics and photochemical data for use in stratospheric modeling, JPL Publ., 87-4I, 1987.

Douglass, A. R., C. H. Jackman, and R. S. Stolarski, Comparison of model results transporting the odd nitrogen family with results transporting separate odd nitrogen species, J. Geophys. Res., 94, 9862-9872, 1989.

Fabian, P., J. A. Pyle, and R. J. Wells, The August 1972 solar proton event and the atmospheric ozone layer, Nature, 277, 458-460, 1979.

Frederick, J. E., Solar corpuscular emission and neutral chemistry in the Earth's middle atmosphere, J. Geophys. Res., 81, 31793186, 1976

Frederick, J. E., B. W. Guenther, P. B. Hays, and D. F. Heath, Ozone profiles and chemical loss rates in the tropical stratosphere deduced from backscatter ultraviolet measurements, J. Geophys. Res., 83, 953-958, 1978.

Guthrie, P. D., C. H. Jackman, and A. M. Thompson, Methane and carbon monoxide: Budgets and seasonal behavior in a 2-D model simulation (abstract), Eos Trans. AGU, 65, 834, 1984.

Hampson, R. F., Chemical kinetic and photochemical data sheets for atmospheric reactions, Rep. FAA-EE-80-17, Natl. Bur. of Stand., Washington, D. C., 1980.

Heath, D. F., A. J. Krueger, and P. J. Crutzen, Solar proton event: Influence on stratospheric ozone, Science, 197, 886-889, 1977.

Jackman, C. H., and R. D. McPeters, The response of ozone to solar proton events during solar cycle 21: A theoretical interpretation, J. Geophys. Res., 90, 7955-7966, 1985.

Jackman, C. H., and R. D. McPeters, Solar proton events as tests for the fidelity of middle atmosphere models, Phys. Scr., T18, 309-316, 1987.

Jackman, C. H., and P. E. Meade, Effect of solar proton events in 1978 and 1979 on the odd nitrogen abundance in the middle atmosphere, J. Geophys. Res., 93, 7084-7090, 1988.

Jackman, C. H., H. S. Porter, and J. E. Frederick, Upper limits on production rate of NO per ion pair, Nature, 280, 170, 1979.

Jackman, C. H., J. E. Frederick, and R. S. Stolarski, Production of odd nitrogen in the stratosphere and mesosphere: An intercomparison of source strengths, J. Geophys. Res., 85, 7495-7505, 1980.

Jackman, C. H., R. S. Stolarski, and J. A. Kaye, Two-dimensional monthly average ozone balance from limb infrared monitor of the stratosphere and stratospheric and mesospheric sounder data, $J$. Geophys. Res., 91, 1103-1116, 1986.

Jackman, C. H., P. D. Guthrie, and J. A. Kaye, An intercomparison of nitrogen-containing species in Nimbus 7 LIMS and SAMS data, J. Geophys. Res., 92, 995-1008, 1987.

Johnston, H. S., and J. Podolske, Interpretation of stratospheric photochemistry, Rev. Geophys., 16, 491-519, 1978.

Laird, C. M., E. J. Zeller, and G. A. M. Dreschhoff, Comments on "Relative contributions of tropospheric and stratospheric sources to nitrate in Antarctic snow" by M. R. Legrand and R. J. Delmas, Tellus, 40B, 233-236, 1988.

Legrand, M. R., and R. J. Delmas, Relative contributions of tropospheric and stratospheric sources to nitrate in Antarctic snow, Tellus, 38B, 236-249, 1986

Legrand, M. R., F. Stordal, I. S. A. Isaksen, and B. Rognerud, A model study of the stratospheric budget of odd nitrogen, including effects of solar cycle variations, Tellus, 4lB, 413-426, 1989.

Loewenstein, M., J. R. Podolske, K. R. Chan, and S. E. Strahan, Nitrous oxide as a dynamical tracer in the 1987 Airborne Antarctic Ozone Experiment, J. Geophys. Res., 94, 11,589-11,598, 1989.

Maeda, K., and D. F. Heath, Stratospheric ozone response to a solar proton event: Hemispheric asymmetries, Pure Appl. Geophys., 119, 1-8, 1980/1981.

McElroy, M. B., and R. J. Salawitch, Changing composition of the global stratosphere, Science, 243, 763-770, 1989.

McPeters, R. D., A nitric oxide increase observed following the July 1982 solar proton event, Geophys. Res. Lett, 13, 667-670, 1986.

McPeters, R. D., and C. H. Jackman, The response of ozone to solar proton events during solar cycle 21: The observations, $J$ Geophys. Res., 90, 7945-7954, 1985.

McPeters, R. D., C. H. Jackman, and E. G. Stassinopoulos, Observations of ozone depletion associated with solar proton events, J. Geophys. Res., 86, 12,071-12,081, 1981.

Natarajan, M., and L. B. Callis, Examination of stratospheric ozone photochemistry in light of recent data, Geophys. Res. Lett., 16, $473-476,1989$.

Newell, R. E., J. W. Kidson, D. G. Vincent, and G. J. Boer, The General Circulation of the Tropical Atmosphere and Interations With Extratropical Latitude, vol. 1, MIT Press, Cambridge, Mass., 1972.

Porter, H. S., C. H. Jackman, and A. E. S. Green, Efficiencies for production of atomic nitrogen and oxygen by relativistic proton impact in air, J. Chem. Phys., 65, 154-167, 1976.

Reagan, J. B., R. E. Meyerott, R. W. Nightingale, R. C. Gunton, R. G. Johnson, J. E. Evans, W. L. Imhof, D. F. Heath, and A. J. Krueger, Effects of the August 1972 solar particle events on stratospheric ozone, J. Geophys. Res., 86, 1473-1494, 1981.

Rosenfield, J. E., M. R. Schoeberl, and M. A. Geller, A computation of the stratospheric diabatic residual circulation using an accurate radiative transfer model, J. Atmos. Sci., 44, 859-876, 1987.

Rusch, D. W., J.-C. Gerard, S. Solomon, P. J. Crutzen, and G. C. Reid, The effect of particle precipitation events on the neutral and ion chemistry of the middle atmosphere, I, Odd nitrogen, Planet. Space Sci., 29, 767-774, 1981.

Solomon, S., and P. J. Crutzen, Analysis of the August 1972 solar proton event including chlorine chemistry, J. Geophys. Res., 86, $1140-1146,1981$.

Solomon, S., D. W. Rusch, J.-C. Gerard, G. C. Reid, and P. J. Crutzen, The effect of particle precipitation events on the neutral and ion chemistry of the middle atmosphere, 2, Odd hydrogen, Planet. Space Sci., 29, 885-892, 1981.

Solomon, S., G. C. Reid, D. W. Rusch, and R. J. Thomas, Mesospheric ozone depletion during solar proton events, paper presented at the Sixth ESA-PAC Meeting, Eur. Space Agency, Interlaken, Switzerland, April 12-19, 1983a.

Solomon, S., G. C. Reid, D. W. Rusch, and R. J. Thomas, Mesospheric ozone depletion during the solar proton event of July 13, 1982, 2, Comparison between theory and measurements, Geophys. Res. Lett., 10, 257-260, $1983 b$.

Swider, W., and T. J. Keneshea, Decrease of ozone and atomic oxygen in the lower mesosphere during a PCA event, Planet. Space Sci., 21, 1969-1973, 1973.

Thomas, R. J., C. A. Barth, G. J. Rottman, D. W. Rusch, G. H. Mount, G. M. Lawrence, R. W. Sanders, G. E. Thomas, and L. E. Clemens, Mesospheric ozone depletion during the solar proton event of July 13, 1982, 1, Measurement, Geophys. Res. Lett., 10 253-255, 1983

Trenberth, K. E., and J. G. Olson, Temperature trends at the south pole and McMurdo Sound, J. Clim. 2, 1196-1206, 1989.

Weeks, L. H., R. S. CuiKay, and J. R. Corbin, Ozone measurements in the mesosphere during the solar proton event of November 2, 1969, J. Atmos. Sci., 29, 1138-1142, 1972.

Whitten, R. C., and I. C. Poppoff, Fundamentals of Aeronomy, p. 251, John Wiley, New York, 1971.

Wofsy, S. C., Temporal and latitudinal variations of stratospheric trace gases: A critical comparison between theory and experiment, J. Geophys. Res., 83, 364-378, 1978.

Zeller, E. J., and B. C. Parker, Nitrate ion in Antarctic firn as a marker for solar activity, Geophys. Res. Lett., 8, 895-898, 1981

Zeller, E. J., G. A. M. Dreschhoff, and C. M. Laird, Nitrate flux on the Ross Ice Shelf, Antarctica and its relation to solar cosmic rays, Geophys. Res. Lett., 13, 1264-1267, 1986.

A. R. Douglass, C. H. Jackman, R. D. McPeters, and R. B. Rood, Laboratory for Atmospheres, Code 616, NASA Goddard Space Flight Center, Greenbelt, MD 20771.

P. E. Meade, Department of Astrophysical, Planetary, and Atmospheric Sciences, University of Colorado, Boulder, CO 80309.

(Received September 14, 1989; revised January 2,1990 ; accepted January 3, 1990. 